from the Thung Song Limestone, which they resemble lithologically and which lies unconformably beneath the Group in the east of the Thai Peninsula. It could be argued that the terrigeneous detritus in the Phuket Group was derived from rocks beneath and to the east of the Thung Song Limestone, representing the northward extension of the Lower Palaeozoic geosynclinal rocks now exposed in the Malay Peninsula. However, until more conclusive evidence is found, the direction of provenance will remain in doubt. On broad regional grounds we see no reason to dismiss the ideas of earlier Dutch workers that the source lay to the east, rather than to the west as has been suggested by Jones (1968), Burton (1970) and Ridd.

\title{
References
}

Burton, C. K. 1970. The Palaeotectonic status of the Malay Peninsula. Palaeogeography, Palaeoclimatol., Palaeoecol. 7, 51-60.

Jones, C. R. 1968. Lower Palaeozoic rocks of Malay Peninsula. Bull. Am. Ass. Petrol. Geol. 52, 1259-78.

A. H. G. MITCHELL,

Dept. of Geology and Mineralogy

Parks Road, Oxford

B. YOUNG,

Institute of Geological Sciences,

5 Princes Gate, London, S.W.7.

10th June 1971
W. JANTARANIPA,

Dept of Geology

University of Strathclyde

George Street, Glasgow, C.1.

\section{Tectonic ripples and associated minor structures in the Silurian rocks of Denbighshire}

SIR,-Warren, Harrison, Wilson, Smith \& Nutt (1970) are mistaken in supposing that theirs is the first reference to the combination of lineation, small folds (ripples) and thin calcite-quartz sheets from the Silurian of Denbighshire. There is a considerably earlier account of an identical association in the Geological Survey memoir of the Wrexham district in which the Silurian rocks of the Llangollen Synclinorium are described (Wedd, Smith \& Wills, 1927, p. 91). In addition there is later work by Nettle (1964) and myself (Nicholson, 1966) also from Llangollen. The mullions of Warren et al. (1970), however, do not seem to have been described before.

Both Nettle (1964, p. 223) and Warren et al. (1970, p. 59) have proposed that the small folds they describe are later than the cleavage and larger folds of the rocks that contain them and require for their formation some special deformation at their own level not found generally in the region. I think rather that the two are expressions of the same deformation; buckling, often with flexural slip, being restricted to horizons at which the relatively stiff but often foliated calcite-quartz sheets occur, such deformation changing quickly into layer-parallel shortening in the mudstone and shale beyond (Nicholson, 1964, 1966, pp. 120-4). Broadly this also was the early survey view (Wedd et al., 1927).

In some ways the evidence in the Llangollen area is better developed to support an argument that the fold and cleavage structures belong together than the area to its north in which Warren et al. have worked. Thus I give an outline of the Llangollen argument below. Before I do so, however, there is one objection which might be made by Warren et al. to the proposition made above. This objection is that most of their small folds appear to occur at levels at which no calcite-quartz layers are known so that buckling, etc., as described above could not occur. However, at Llangollen it is clear that no calcite-quartz sheet reaches ground surface; traced upwards in a quarry the sheets are increasingly weathered towards it and as far as I am aware there is no positive evidence 
that calcite-quartz sheets do not always occur at levels with small folds. Thus when examined in detail at localities A and $H$ of Warren et al. $(1970$, p. 55) a folded surface without a calcite-quartz coating always has a gap as its equivalent in the adjoining rock wall. In contrast at locality $F$ where a sheet is present coating a mudstone surface there is a calcite-quartz sheet as a part of the sequence in the quarry wall next to it and no gap. Thus it seems likely to me that the distinctive folds described by Warren $e t$ al. form the cast of a now weathered calcite-quartz sheet.

As shown on the accompanying sketch calcite-quartz sheets parallel to bedding occur in both north and south limbs of the Llangollen synclinorium. In the north limb sheets are folded while in the south limb they are boudined. Where boudined they lie near the gently dipping cleavage but where folded lie at a large angle to cleavage. Furthermore, in the north limb there are conspicuous discordant sheets very nearly parallel to cleavage in the rocks next to the concordant ones: these discordant sheets are boudined. Thus there is every indication (Nicholson, 1966, pp. 120,125) that the deformation recorded by the calcite quartz sheets is part of the general rock strain and not something special and later.

The conclusion of the last paragraph need not imply that the two orders of fold, small and large, were formed at exactly the same time, however, and I have already suggested that the smaller are older than the much larger ones round which they lie (Nicholson, 1966, p. 120). Thus my explanation can accommodate the observation of Warren et al. (1970, pp. 59-60) that their small folds usually overturn to the north whether they lie on north or south limb of a major fold; overturn could have developed before the major folds grew.

$S$

River Dee

$N$

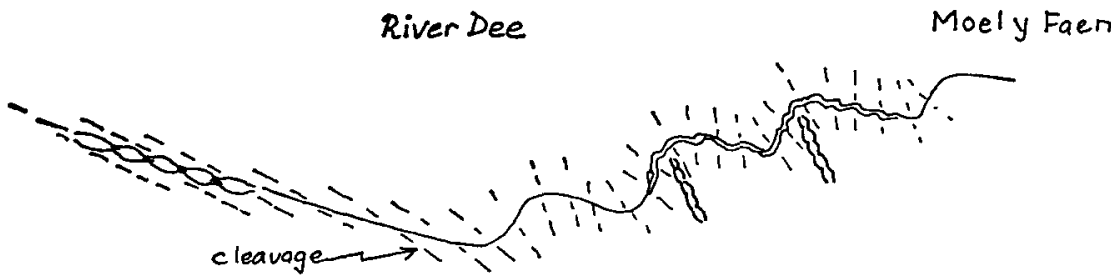

Figure 1. Diagrammatic section through the Llangollen synclinorium showing deformation in calcite-quartz sheets and relation to cleavage. Sheets much exaggerated in thickness. Faults ignored.

It has to be admitted of course that making the small folds earlier does not itself explain the consistent overturn reported by Warren et al. although the generally rather weakly developed cleavage in north Denbigh suggests that an overturn could well survive cleavage formation. It may be suggested that perhaps overturn developed from flexural slip of a kink-zone type in the most foliate sheets whose folds in the Llangollen area at least are rather sharply hinged (Nicholson, 1966, Fig. 2). Less well foliated sheets at Llangollen which may have behaved more like monolayers have more rounded fold hinges and a symmetrical shape.

The following sequence of events seems to fit both north Denbigh and Llangollen developments:

1. Formation of calcite-quartz sheets-reasons not clear.

2. Production of lineation on concordant sheets; clearly evidence of movement on what must amount to bedding plane faults; curiously the lineation often is about normal to later fold axes.

3. General rock strain; development of buckles of calcite-quartz sheets, initiation of cleavage.

4. Development of large folds and accentuation of cleavage; some small fold tightening, perhaps where cleavage is strongest. 
To me the major problems are the production of the sheets themselves and their fabric, and the development of the lineation on them rather than their folds, etc.; once the sheets are present in the sequence their particular deformation features seem to follow from the regional deformation.

\section{References}

Nettle, J. T. 1964. Fabric analysis of a deformed vein. Geol. Mag. 101, 220-7.

Nicholson, R. 1964. Fabric analysis of a deformed vein. Geol. Mag., 101, 474.

1966. The problem of origin, deformation and recrystallization of calcite-quartz bodies. Geol. J. 5, 117-26.

Warren, P. T., Harrison, R. K., Wilson, H. E., Smith, E. G. \& Nutt, M. J. C. 1970. Tectonic ripples and associated minor structures in the Silurian rocks of Denbighshire, North Wales. Geol. Mag. 107, 51-60.

Wedd, C. B., Smith, B. \& Wills, L. J. 1927. The geology of the country around Wrexham. Mem. geol. Surv. England and Wales.

Department of Geology

The University

Manchester M13 9PL.

27th April 1971

\section{Tectonic ripples and associated minor structures in the Silurian rocks of Denbighshire}

SIR,-We are grateful to Dr Nicholson for his interest in our paper (Geol. Mag. 107, 51-60). In the absence of photographs illustrating the megascopic features of the calcite-quartz bodies in the Silurian rocks of the Llangollen area (described by Wedd et al. 1927; Nettle, 1964, and himself, 1966), we have examined a number of localities there. Whilst there is a superficial resemblance between the structures associated with these bodies and certain examples of some of our structures, we cannot agree, for the reasons outlined below, that there is any real similarity, in either appearance or origin.

The calcite veins in the Llangollen area, for example at Moel y Faen Quarry, occur along high-angle joints which are members of a conspicuous set of master joints, locally parallel to the highly inclined bedding. In some cases, as Nicholson himself states $(1966$, p. 118), the veins are not parallel to the bedding. In contrast, our tectonic ripple horizons invariably correspond to the generally low-angle bedding of the Denbigh area.

The presence of calcite, we believe, is not a prerequisite for the formation of tectonic ripples. Indeed, as we pointed out (p. 58) there is no evidence that the carbonate seen, for example, at Gorsedd Brân (Loc. F) predated the initiation of the shearing movements responsible for them, any more than did the chlorite-quartz association at Creigiau Quarry (Loc. B). Furthermore we cannot agree that calcite has been present at all our tectonic ripple horizons, or that when present it played the same role as in the Llangollen structures. The choice of the Gorsedd Brân specimen for a photomicrograph was governed by its obvious photogenic qualities in illustrating the shape and dimensions of the tectonic ripples. Since the publication of our paper four further localities have been recorded in North Wales and our attention has been drawn to the occurrence of tectonic ripples in Ordovician and Silurian rocks of the Lake District (R. B. Rickards, in litt.) and elsewhere in Britain and Continental Europe. In the majority of cases the characteristic appearance is of 'positive' and 'negative' ripples separated only by mylonitic crush rock. Removal of this mylonite gives rise to the gap referred to by Dr Nicholson.

More significantly, tectonic ripples and the associated structures are all developed 